\title{
Et spedbarn med akutte slappe pareser
}

\author{
En fire måneder gammel pike utviklet i løpet av kort tid nedsatt suge- \\ kraft, svakt skrik og generell kraftsvekkelse og hypotoni. Hun ble inn- \\ lagt på sykehus og det ble igangsatt omfattende utredning, men anam- \\ nesen var avgjørende for å stille riktig diagnose.
}

En fire måneder gammel tidligere frisk pike ble akutt innlagt i sykehus fordi hun i løpet av det siste døgnet var blitt slapp og svak i hele kroppen og hadde sluttet å die. Den siste uken hadde hun hatt nedsatt sugekraft og de siste to dagene svakere skrik. I løpet av den samme perioden hadde hun heller ikke hatt avføring. Svangerskapet hadde vært ukomplisert, med normal fødsel til termin, og det var normal vekst og utvikling inntil det aktuelle. Barnet var uvaksinert. Hun var fullammet og hadde ikke fått annen føde enn morsmelk. Ved undersøkelse fant man uttalt generell muskelsvakhet og hypotoni. Hun siklet og hadde surklete respirasjon og hun klarte ikke å lukke munnen rundt brystvorten ved forsøk på amming. Det var sparsomme tarmlyder. Pasienten var afebril, og $\emptyset v r i g$ organstatus var normal.

Man hadde ingen åpenbar forklaring på pasientens symptomer. Hos et spedbarn med akutt/subakutt redusert allmenntilstand uten kjent årsak må man tenke på tilstander som krever rask behandling, først og fremst alvorlig infeksjon og tarminvaginasjon. Andre årsaker kan være elektrolyttforstyrrelser og dehydrering, medfødte hjertefeil, metabolske sykdommer og forgiftninger.

Orienterende blodprøver, inkludert infeksjonsmarkører, syre-base-status, elektrolytter, glukose, thyreoideastatus, kreatinkinase (CK), hjertemarkører, hematologi og nyre- og leverprøver var normale. Urinstiks var negativ. Røntgen thorax og røntgen oversikt abdomen var normale, mens ultralyd abdomen viste rikelig med fekalia i colon. Pasienten fikk sepsisbehandling med ampicillin og gentamicin, og hun ble ernært med morsmelk på nasogastrisk sonde.

Ved infeksjoner hos spedbarn kan redusert allmenntilstand og redusert matinntak være viktigste sykdomstegn, mens øvrige symptomer er vage og uspesifikke. Vår pasient fikk derfor sepsisbehandling til tross for afebrilitet og lave infeksjonsmarkører.

Pasientens symptomer og funn med pareser pekte mot nervesystemet, og hun ble undersøkt av barnenevrolog dagen etter innleggel- sen. Barnet ga god blikkontakt, men det ble nå også bemerket ptose, hengende hode ved traksjon og dårlig hodekontroll. Hun løftet begge armene og hadde normale senereflekser. Hun hadde normal hodeomkrets og det var ingen dysmorfe trekk. Det var normale funn i spinalvæske og ved ultralyd caput.

Det neste døgnet fikk pasienten forverret svelgfunksjon og tydelig redusert sugerefleks (bulbære pareser). Hun var mimikkfattig og fulgte bare kortvarig blikket oppad. Det var tilkommet uttalt hyporefleksi og ikke-utløsbare abdominalreflekser. Fordi det ikke var holdepunkter for bakteriell infeksjon, ble antibiotika seponert.

Aktuelle differensialdiagnoser ved akutte/ subakutte lammelser hos barn inkluderer Guillain-Barrés syndrom, Miller-Fishers syndrom (en variant av Guillain-Barrés syndrom), spedbarnsbotulisme, myasthenia gravis, myelitt (f.eks. poliomyelitt eller transvers myelitt), encefalitt (f.eks. hjernestammeencefalitt eller akutt disseminert encefalomyelitt), cerebralt vaskulært insult, annen nevromuskulær sykdom slik som ved myositt, og i tillegg metabolske sykdommer og forgiftninger. Det ble igangsatt en bred utredning.

Pasienten hadde nå overfladisk respirasjon, med sekretstagnasjon og problemer med à opprettholde frie luftveier. To døgn etter innleggelsen ble hun overflyttet til intensivavdeling, der hun fikk respirasjonsstøtte i form av CPAP. Det ble påvist rhinovirus i nasopharynxsekret og overlappsatelektase $i$ høyre lunge. Man fant også enterovirus i nasopharynxsekret, men ikke i serum og spinalvæske.

Både rhinovirus og non-polioenterovirus kan gi luftveisinfeksjon med økt slimdanning, som sammen med nedsatt hoste- og respirasjonskraft kan ha ført til atelektase. Non-polioenterovirus er beskrevet som en sjelden årsak til akutte slappe pareser (1). Høsten 2014 ble det i Nord-Amerika rapportert flere tilfeller av akutte slappe pareser samtidig med et utbrudd av luftveisinfeksjon forårsaket av enterovirus D68. Hos flere av barna ble enterovirus D68 påvist luftveissekret (2). To tilsvarende tilfeller ble rapportert i Norge høsten 2014 (3). Folke-

\author{
Marit Lunde Dalen \\ Per Kristian Knudsen \\ Barnemedisinsk avdeling \\ Klaus Bye \\ Barneintensiv avdeling \\ Kvinne- og barneklinikken \\ Oslo universitetssykehus, Ullevål \\ Kristian Bernhard Nilsen \\ Seksjon for klinisk nevrofysiologi \\ Avdeling for nevrologi \\ Oslo universitetssykehus \\ og \\ Institutt for nevrovitenskap \\ Norges teknisk-naturvitenskapelige universitet \\ og \\ Avdeling for arbeidspsykologi og -fysiologi \\ Statens arbeidsmiljøinstitutt
}

\section{Liv Marit Rørvik}

Norges miljø- og biovitenskapelige universitet, Veterinærhøgskolen

Oslo

Gro Anita Gauslå Tessem

Seksjon for barnenevrologi Barneavdeling for nevrofag Kvinne- og barneklinikken

Oslo universitetssykehus, Ullevål 


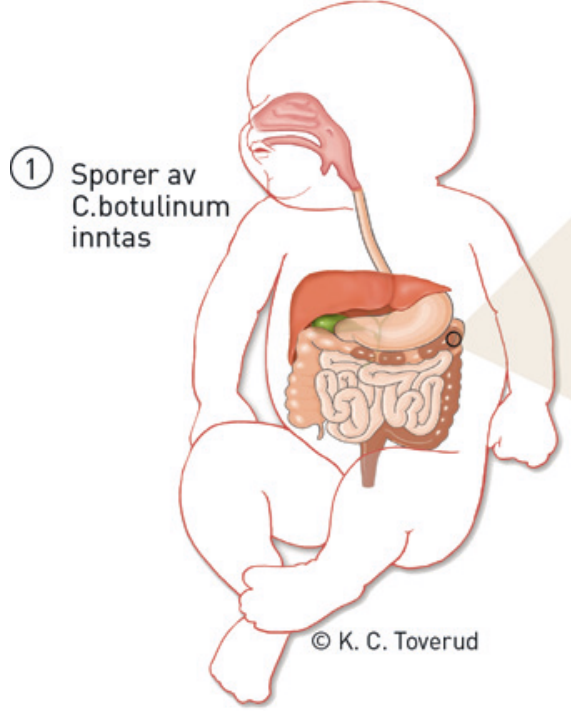

Figur 1 Patogenese ved spedbarnsbotulisme

helseinstituttet har derfor utvidet sin overvåking av akutte slappe pareser, og skal ved alle tilfeller hos barn under 15 år motta prøver for analyse av enterovirus D68 i luftveissekret (4) i tillegg til poliovirus i feces.

Pasienten hadde negative funn ved analyser for nevrotrope virus i spinalvæske og virusserologi. Analysen av enterovirus D68 var ikke etablert da barnet ble innlagt. Hun hadde ikke poliovirus $i$ avføringen og heller ikke de typiske asymmetriske paresene som ved poliomyelitt. MR caput og medulla med kontrast var normal. Metabolsk utredning var uten tegn til mitokondriepati eller annen metabolsk sykdom. Det var ikke serumantistoffer mot acetylkolinreseptor. Fordi man ikke kunne utelukke Miller-Fishers syndrom fikk pasienten to doser gammaglobulin intravenøst. Det ble deretter observert bedret motorikk og muskelkraft, men serum-gangliosidantistoffer forbundet med tilstanden ble ikke påvist.

Tre dager etter innleggelsen ble det utført nevrofysiologisk undersøkelse med nevrografi og elektromyografi (EMG). Det var normale ledningshastigheter, ingen amplitudereduksjon ved lavfrekvent repetitiv stimulering $(3 \mathrm{~Hz})$, en ikke-signifikant amplitudeøkning ved høyfrekvent repetitiv stimulering $(50 \mathrm{~Hz})$ og ingen spontanaktivitet. Det ble konkludert med normale funn, og spesielt ikke tegn på Guillain-Barrés syndrom, nevromuskulær transmisjonsforstyrrelse eller spinal muskelatrofi.
Bred utredning ga ingen forklaring på de alvorlige symptomene. Pasienten hadde akutte, symmetriske, descenderende slappe pareser og muskulær hypotoni, men ingen encefalopati eller feber. Dette er typiske funn ved spedbarnsbotulisme, hvor redusert suge- og brekningsrefleks, innskrenkede øyebevegelser og nedsatt mimikk sees før affeksjon av øvrig muskulatur. Senerefleksene kan være normale eller reduserte, og obstipasjon på grunn av tarmparalyse er vanlig. Til tross for manglende informasjon om smittekilde var det sterk klinisk mistanke om spedbarnsbotulisme, og anamnesen ble gjennomgått på nytt.

Pasienten hadde ikke hatt navleinfeksjon (sårbotulisme) eller kontakt med jord (sporer ijordsmonn). Hun var fullammet, men på direkte spørsmål kom det frem at hun ti dager før symptomdebut ved ett tilfelle hadde fått smake italiensk økologisk honning og fransk økologisk mandelpuré på en smokk. På grunn av disse opplysningene ble mistanken om spedbarnsbotulisme styrket, og Folkehelseinstituttet og Norges miljø- og biovitenskapelige universitet (NMBU), Veterinærhøgskolen ble kontaktet for konferering rundt diagnostikk og behandling.

Ved mistenkt spedbarnsbotulisme må botulinumantitoksin gis tidligst mulig fordi det da kan nøytralisere sirkulerende toksin før dette bindes irreversibelt til de nevromusku- lære synapsene. Tilgjengelig botulinumantitoksin (basert på immunisert hest) i Norge var på det aktuelle tidspunktet utgått på dato. Man kontaktet derfor produsenten av BabyBIG, som er et humanspesifikt botulinumantitoksin med dokumentert effekt og sikkerhet hos spedbarn $(5,6)$, men med begrenset tilgjengelighet. Pasienten hadde på tidspunktet ikke progredierende symptomer og diagnosen var fortsatt noe usikker. Man valgte derfor å avvente antitoksinbehandling, men sendte serum, feces og inntatte næringsmidler til NMBU Veterinærhøgskolen og til Avdeling for mikrobiologi ved Oslo universitetssykehus, Ullevål for botulismediagnostikk.

C-reaktivt protein (CRP) steg til 86, og det ble på nytt gitt antibiotika (cefotaksim). Hun fikk, i tillegg til ernæring med morsmelk, laktobasiller (ldoform per os) for å styrke konkurrerende tarmflora og hindre utbredelse av botulinumsporer i tarm. Obstipasjonen ble behandlet med klyster. Grunnet vedvarende mistanke om spedbarnsbotulisme ble det gitt BabyBIG på dag 11 etter innleggelsen. Dette ble valgt dels grunnet dokumentasjon på effekt og sikkerhet hos spedbarn, dels fordi tilgjengelig antitoksin i Norge var utgått på dato.

Man observerte i løpet av de neste dagene tydelig bedring i svelgfunksjon og hostekraft samt kraftigere skrik. Barnet klarte å lukke munnen og begynte å suge litt på smokk, 
fikk bedre hodekontroll og løftet hodet $i$ mageleie. Hun var fortsatt hypoton og klarte ikke å spise selv, men var uten respiratorisk besvær. Et par dager før utskrivning ble en anaerob sporedannende grampositiv stavbakterie isolert i prøver fra pasientens avføring. Denne stammen ble ved hjelp av 165 rDNA-sekvensering identifisert som Clostridium botulinum. Intraperitoneal injeksjon av prøvemateriale på mus (musetest) ga symptomer på botulisme hos musene som fikk ufortynnet pasientserum og mus som fikk dyrkingskulturer fra pasientavføring og mandelpuré. Tilsvarende ble ikke funnet $i$ honningen. Bare én av to mus som fikk intraperitoneal injeksjon med pasientserum utviklet symptomer, hvilket tydet på lav toksinmengde. Ved nøytralisasjonstest, der prøvemateriale fra pasienten var tilsatt antitoksin før injeksjon, forble musene som fikk antitoksin A friske, hvilket tydet på botulisme type $A$.

Etter 22 dager på sykehus ble pasienten utskrevet. Hun var fortsatt hypoton, med hengende hode ved traksjon, men sittende hadde hun relativt god hodekontroll. Det var forbedret kraft i alle ekstremiteter. Hun hadde gjenvunnet normale reflekser og spiste nå økende mengder morsmelk på flaske. Ved poliklinisk kontroll etter tre måneder viste psykomotorisk undersøkelse at hun var aldersadekvat.

I etterkant av innleggelsen ble resultatene fra den nevrofysiologiske undersøkelsen reanalysert. Ved undersøkelsestidspunktet ble motorisk amplitude vurdert som normal. Etter sammenlikning med publiserte normalverdier for aldersgruppen ble denne nå vurdert som for lav (7). Pasienten hadde en amplitudeøkning ved høyfrekvent repetitiv stimulering på $80 \%$ etter ti sekunder. Ved undersøkelsestidspunktet var grensen for patologisk amplitudeøkning satt til $100 \%$, som er praksis ved andre presynaptiske nevromuskulære transmisjonsforstyrrelser. Etter litteraturgjennomgang vurderte man nå dette som for strengt for botulisme, der amplitudeøkning helt ned i $20-30 \%$ etter høyfrekvent repetitiv stimulering anses som uttrykk for presynaptisk transmisjonsforstyrrelse (8). Samlet ble resultatene fra den nevrofysiologiske undersøkelsen nå vurdert som forenlig med spedbarnsbotulisme.

\section{Diskusjon}

Botulisme skyldes forgiftning med botulinumtoksin, som enten produseres in vivo av levende $C$. botulinum (spedbarnsbotulisme og sårbotulisme) eller inntas som ferdig dannet toksin (næringsmiddeloverført botulisme og iatrogen botulisme). Bakteriens sporer finnes utbredt i jordsmonn, og de fleste tilfellene er rapportert fra $\operatorname{USA}(9,10)$. Det finnes åtte ulike toksintyper, betegnet toksin $\mathrm{A}-\mathrm{H}$. Toksin A, B, E (og sjeldnere F, $\mathrm{G}$ og $\mathrm{H}$ ) gir sykdom hos mennesket, og stammer som produserer toksin B eller E er de vanligste i Nord-Europa (11).

Spedbarnsbotulisme er en sjelden tilstand i Norge, med fem publiserte tilfeller siden første beskrivelse i 1997 (11, 12). Sporer i honning er en kjent smittekilde, og honning skal ikke gis til barn under 12 måneder (13). Tilstanden forekommer hos barn i alderen 1 uke-1 år (median 3-4 måneder). Manglende konkurrerende tarmflora er én av faktorene som bidrar til sårbarhet hos spedbarn (14). Tilstanden oppstår når sporer av C. botulinum (sjeldnere C. baratii eller C.butyricum) inntas og spirer intraluminalt $i$ tykktarm, der bakterien produserer botulinumtoksin. Toksinet spres via blodet til perifere nevromuskulære synapser, der det hindrer frigjøring av acetylkolin og dermed hemmer presynaptisk nevromuskulær signaloverføring (fig 1).

Bulbær muskulatur har høy blodtilførsel og tett innervering og rammes i regelen først. Bulbære pareser kan hos spedbarn fremstå som dårlig sugekraft og spisevansker, svakt skrik, sikling og obstruktiv apné Færre enn $25 \%$ har autonom dysfunksjon, som blæreparese, paralytisk ileus og fluktuerende puls og blodtrykk $(15,16)$. Det er ikke endret bevissthet eller sensoriske utfall. Uten sekundærinfeksjon er det heller ingen feber.

Siden spedbarnsbotulisme kan opptre som akutt/subakutt nedsatt allmenntilstand uten kjent årsak, er det vanlig at man først mistenker sepsis. Tilstanden blir også ofte feildiagnostisert som polyradikulonevropati, myasthenia gravis eller sykdom i det sentrale nervesystemet (15-17). Diagnosen må ofte baseres utelukkende på anamnese og klinisk undersøkelse. Diagnostisk bekreftelse med standardmetode (musetest) for å påvise toksin i pasientserum eller toksin i dyrkningskultur (fra feces eller annet materiale) er tidkrevende. Musetesten tar ca. sju døgn, med ytterligere et par dager for å fastslå toksintype ved nøytralisasjonstest. NMBU Veterinærhøgskolen har nylig erstattet musetest av dyrkningskultur med en metode der multipleks polymerasekjedereaksjonstest (PCR) brukes for å påvise toksingenene $\mathrm{A}, \mathrm{B}$ og $\mathrm{E}$ i bakterieisolater fra pasientavføring og næringsmidler. Denne metoden kan gi raskere diagnose, men var ikke etablert da vår pasient ble innlagt. Nevrofysiologisk diagnostikk kan være nyttig, men krever nøyaktige prosedyrer og trent personale og er direkte relatert til symptomgrad (8).

Behandlingen ved spedbarnsbotulisme består av botulinumantitoksin, ivaretakelse av vitale funksjoner og behandling av komplikasjoner. Folkehelseinstituttet er ansvarlig for tilgang på antitoksin i Norge. Anbe- falt førstevalg - også til spedbarn - er heptavalent antitoksin mot toksin type $A, B, C, D$, E, F og G, som produseres på immunisert hest av Cangene Corporation. På grunn av teoretisk risiko for sensibilisering og alvorlig allergisk reaksjon er man i noen land tilbakeholdne med å bruke antitoksin fra dyr til spedbarn. Fordeler med Cangenes preparat er bred dekning mot flere serotyper og god tilgjengelighet (11). To norske spedbarn er nylig blitt vellykket behandlet uten komplikasjoner med dette preparatet (J. Barlinn og G.A.G. Tessem, personlig meddelelse). Anbefalt andrevalg er BabyBIG, et humanspesifikt antitoksin mot toksin type A og B, med dokumentert effekt hos spedbarn $(5,6)$. Amerikanske data viser at dette preparatet forkorter liggetid på sykehus (fra $\mathrm{i}$ gjennomsnitt 5,7 uker til 2,6 uker), tid med respiratorstøtte og tid med ernæring via nasogastrisk sonde. Behandling gitt innen 72 timer etter innleggelsen har størst effekt, men også senere administrasjon kan redusere graden av symptomer og forkorte sykdomsforløpet (5). Ulemper er høy pris og at produktet må bestilles fra USA i hvert enkelt tilfelle.

Fordi bakteriedrap kan føre til økt toksinfrigjøring, skal ukomplisert botulisme ikke behandles med antibiotika. Ved sekundære infeksjoner kan det være aktuelt med antibiotika som ikke har effekt mot C.botulinum. Aminoglykosider kan forverre den nevromuskulære blokaden og er kontraindisert (14). Det er vanskelig å fastslå om antibiotikabehandlingen som ble gitt til vår pasient de første to dagene kan ha påvirket utviklingen av symptomer.

Prognosen ved spedbarnsbotulisme er god, med full restitusjon så lenge man unngår alvorlige komplikasjoner i forløpet. Det er, i tillegg til sekundære infeksjoner, særlig risiko for aspirasjon og hypoventilering. Hypoksisk skade ved respirasjonsstans som følge av okklusjon av sekret eller lammelse av faryngeal muskulatur kan forekomme, men dødsfall er sjelden. Hos barn innlagt med spedbarnsbotulisme er mortaliteten ca. $1 \%(5,10)$. Varigheten av ubehandlet spedbarnsbotulisme er vanligvis 1-2 måneder, med lengre og mer alvorlig forløp ved botulisme type $\mathrm{A}$ enn $\mathrm{B}(5,16)$. Normalisering av motorisk funksjon skjer først når nye nerveender vokser ut og reinnerverer muskelfibrene. I eksperimentelle dyreforsøk tar dette ca. fire uker (16)

\section{Konklusjon}

Spedbarnsbotulisme kan ha et alvorlig og langvarig forløp, men det finnes effektiv behandling $\mathrm{i}$ form av antitoksin dersom denne blir gitt tidlig. Behandlingen gis ved klinisk mistanke og før bekreftelse fra laboratoriediagnostikk foreligger. Typisk presentasjon er akutte, symmetriske, descende- 
rende slappe pareser, normal bevissthet og sensorikk og fravær av feber. Bulbær muskulatur rammes først. Nevrofysiologisk undersøkelse kan være nyttig for å påvise presynaptisk blokade.

Vi takker Gaute Syversen og Tore Taksdal Stubhaug ved Avdeling for mikrobiologi og Petter Strømme ved Barneavdeling for nevrofag ved Oslo universitetssykehus, Ullevål samt Jann Storsæter ved Folkehelseinstituttet.

Pasientens pårørende har gitt samtykke til at artikkelen blir publisert.

\section{Marit Lunde Dalen (f. 1978)}

er ph.d. og lege i spesialisering i pediatri. Forfatter har fylt ut ICMJE-skjemaet og oppgir ingen interessekonflikter.

\section{Per Kristian Knudsen (f. 1965)}

er spesialist i barnesykdommer og overlege i infeksjonssykdommer.

Forfatter har fylt ut ICMJE-skjemaet og oppgir ingen interessekonflikter.

\section{Klaus Bye (f. 1976)}

er spesialist i barnesykdommer og overlege. Forfatter har fylt ut ICMJE-skjemaet og oppgir ingen interessekonflikter.

\section{Kristian Bernhard Nilsen (f. 1974)}

er ph.d., førsteamanuensis og overlege. Forfatter har fylt ut ICMJE-skjemaet og oppgir ingen interessekonflikter.

\section{Liv Marit Rørvik (f. 1947)}

er professor i mattrygghet og har vært ansvarlig for diagnostikk av Clostridium botulinum og botulinumtoksin ved NMBU Veterinærhøgskolen.

Forfatter har fylt ut ICMJE-skjemaet og oppgir ingen interessekonflikter.

\section{Gro Anita Gauslå Tessem (f. 1974)}

er spesialist i barnesykdommer og overlege. Forfatter har fylt ut ICMJE-skjemaet og oppgir ingen interessekonflikter.

\section{Litteratur}

1. Solomon T, Willison H. Infectious causes of acute flaccid paralysis. Curr Opin Infect Dis 2003; 16: 375-81.

2. Greninger AL, Naccache SN, Messacar K et al. A novel outbreak enterovirus D68 strain associated with acute flaccid myelitis cases in the USA (2012-14): a retrospective cohort study. Lancet Infect Dis 2015: 15: 671-82.

3. Pfeiffer HC, Bragstad K, Skram MK et al. Two cases of acute severe flaccid myelitis associated with enterovirus D68 infection in children, Norway, autumn 2014. Euro Surveill 2015; 20: 21062.

4. Nasjonalt folkehelseinstitutt. Uvanlig mange barn syke av enterovirus D68 sist høst. www.fhi.no/ artikler/?id=113508 (16.3.2015)

5. Arnon SS, Schechter R, Maslanka SE et al. Human botulism immune globulin for the treatment of infant botulism. N Engl J Med 2006: 354: 462-71.

6. Lexicomp. Botulism immune globulin (intravenous human): Pediatric drug information. www uptodate.com/contents/botulism-immuneglobulin-intravenous-human-pediatric-druginformation (6.11.2014).

7. Oh SJ. Clinical electromyography: nerve conduction studies. Philadelphia, PA: Lippincott Williams \& Wilkins, 2003: 93-140

8. Gutmann L, Bodensteiner J. Electrodiagnosis of botulism-revisited. J Clin Neuromuscul Dis 2001; 2: 121-2.

9. Pegram PS, Stone SM. Botulism. www. uptodate. com/contents/botulism (6.11.2014)

10. Koepke R, Sobel J, Arnon SS. Global occurrence of infant botulism, 1976-2006. Pediatrics 2008; 122: e73-82

11. Nasjonalt folkehelseinstitutt. Botulisme - veileder for helsepersonell. www. fhi.no/artikler/?id=82659 (27.3.2014).

12. Tølløfsrud PA, Kvittingen EA, Granum PE et al. Botulisme hos spedbarn. Tidsskr Nor Lægeforen 1998: 118: 4355-6.

13. Mattilsynet. Barn under ett år bør ikke spise honning. www. matportalen.no/matvaregrupper/tema/ sukker_og_sote_produkter/barn_under_ett_aar_ bor ikke spise honning (6.11.2014].

14. Bodamer OA, Miller G. Neuromuscular junction disorders in newborns and infants. www.uptodate. com/contents/neuromuscular-junction-disordersin-newborns-and-infants (6.11.2014)

15. Long SS. Infant botulism and treatment with BIGIV (BabyBIG). Pediatr Infect Dis J 2007; 26: 261-2

16. Kliegman RM, Nelson WE, Behrman RE. Nelson textbook of pediatrics. Philadelphia,PA: Saunders Elsevier, 2011: 987-91.

17. Francisco AM, Arnon SS. Clinical mimics of infant botulism. Pediatrics 2007; 119: 826-8.

Mottatt 20.11. 2014, første revisjon innsendt 10.4 . 2015, godkjent 29.5. 2015. Redaktør: Lise Mørkved Helsingen. 